\title{
Julian of Norwich's Mystic Vision as a Site for Rebuilding Societal Unity in the Aftermath of the Black Death
}

\author{
J. D. Fulloon ${ }^{1}$
}

Accepted: 3 May 2021 / Published online: 17 May 2021

(c) The Author(s), under exclusive licence to Springer Nature B.V. 2021

\begin{abstract}
The woman known as Julian of Norwich, the first female author in the English language, survived a pandemic which tore English society apart. The first outbreak of the bubonic plague in Norwich was in 1349 when Julian was only six years old and continued for another twenty-one years of sporadic outbreaks in East Anglia. Despite this formative experience, scholarly treatments of the plague's impact on Julian's writing focus primarily on her use of maternal imagery as a pre-existing general trend in mystic texts which developed a new significance in post-plague religious writing. The divine mother figure was now not only a creator but a source of protection and comfort. While this is certainly true, this is also perhaps a bit myopic. A holistic view of her book of "Showings" reveals that the plague and its aftermath are actually central to her theosophical project. By evoking imagery of the Black Death in her explanation of the Passion and the existence of suffering, Julian of Norwich sought to restore unity to medieval English society through a re-envisioning of the Holy Trinity as Earthly authority figures: family/household, Holy Mother Church, and feudal lord.
\end{abstract}

Keywords Julian of Norwich $\cdot$ Black Death $\cdot$ Plague $\cdot$ Holy Trinity $\cdot$ Mystic

\section{The Plague and the Passion}

The specific circumstances of Julian of Norwich's visions have never been linked to the area of the country in which she lived. Norwich was the English city most devastated by the Black Death. Before the plague, it was the second largest city in England, behind only London in total population; today Norwich is not even among the top five largest cities in the country. Of Norwich's 13,000 inhabitants in 1349, 7104 people, or $56 \%$ of the population, perished in the pandemic. Norwich went from "the second city of the realm" to a proverbial leper colony; the city "not only never

\section{J. D. Fulloon}

dfulloon89@gmail.com

1 English Department, Rutgers University, Newark, NJ, USA 
recovered its position in relation to the rest of England but, in absolute terms, had barely regained its vanished citizens by the end of the sixteenth century" (Ziegler, 1969 , p. 170). It was in this city during this plague that Julian had her seventh birthday. When Julian was thirty years old, she prayed for a bodily sickness "so herde as to deth that I might in that sekeness underfongyn alle my rites of Holy Church, myselfe weneing that I should dye, and that all creatures might suppose the same that seeyn me, for I would have no manner comfort of eardtly life." 1 This desire may have been more than near-suicidal ideation, it may have been a genuine attempt at self-harm. As Rosemary Horrox notes in her collection of primary texts on the Black Death, in her introduction to the section collecting contemporary explanations for the spreading of the plague, "It was widely believed... that the plague could be transmitted by imagination: that a person could be infected by thinking about it... Physicians agreed that people brooding on the plague were more likely to be susceptible to its attack" (1994, p. 107). It is unlikely, however, that Julian's bodily sickness was the bubonic plague. Most writers avoid the issue of the nature of her malady altogether, carefully avoiding the misogynistic trope of "hysteria," while others rule out mental illness and theorize that it was either botulism or pneumonia (Lawes, 2000, pp. 235-236).

David Knowles, however, believes that "it is useless to enquire what the illness was, or indeed whether it is organic or infective or, in part at least, hysteric" (Knowles, 1961, p. 122). To Knowles, what is important is that Julian's description of a near-death experience includes the religious details of the scene as well as the biological, for example the crucifix held by the priest during the last rites at her bedside. Most relevant to this reading of Julian's Shewings is Knowles's views on the nature of the imagery in the divine visions. According to Knowles, the human mind is unable to fully translate the divine messages of God into human understanding; the translation is colored by the disposition of the recipient (1961, p. 134). Due to her childhood experiences during the plague, Julian may have translated the iconic suffering of Jesus during the Passion as being reminiscent of the Black Death, as well as other instances of similar imagery. This observation has been made about the depiction of the Passion in the works of one of Julian's contemporaries, the Monk of Farne, who one scholar speculated "depicts a very mangled and bloody Christ, most likely as a direct response to the suffering he saw firsthand in England" during the Black Death (Essner, 2008, pp. 59-60).

Julian elaborates further on her motivation for desiring this bodily sickness, saying "And this I meant for I would be purged be the mercy of God and liven more to the worshippe of God because of that sekenesse; and that for the more speede in my deth, for I desired to be soone with my God" (60-62). This attitude towards her own sickness is identical to the advice she gives Christians in the following chapters for

\footnotetext{
${ }^{1}$ Due to the Covid-19 pandemic I had no access to the Early English Text Society version of Julian's Shewings, which I have used for Richard Rolle's Meditation A \& B. Instead, I have used Crampton (1994) which presents the original text with a slightly adapted spelling. This quotation is from lines 55-58 of the Long Text, to be found online at: https://d.lib.rochester.edu/teams/text/the-shewings-ofjulian-of-norwich-part-1.
} 
how to view both the suffering of Jesus Christ during the Passion and the suffering in their own ordinary lives. In the imagery she uses to describe the Passion, as well as more mundane suffering, there is a subtle thread of plague imagery not present in the texts by Christian mystics writing before the Black Death. When she speaks of her bodily sickness as a "purge" that will bring her closer to God, she is also speaking of how the Black Death can purge English society and bring Christians closer to God, or rather, closer to the Holy Trinity as she re-envisions it.

Before delving into the imagery used to describe the Passion, there is another notable example of plague imagery in Julian's Shewings which depicts the death of a child: "And in this tyme I saw a body lyand on the erth, which body shewid hevy and oggley withoute shappe and forme, as it were a bolned quave of styngand myre..." (2681-2682). A near-universal observation made about plague victims was how revolting they were as they were dying, smelling foul and covered in black flesh and large tumors (the "buboes" from which the plague gets its name), becoming objects of disgust rather than pity (Ziegler, 1969, p. 20). Julian brings comfort to those who may have lost a child to the plague when, seeing the clean and beautiful soul of the child exit the dying body and ascending to heaven, she writes: "And the bolnehede of the body betokenith gret wretchidnes of our dedly flesh, and the littlehede of the child betokenith the clenes of purity in the soule. And I thowte: With this body belevith no fairehede of this child, no on this child dwellith no foulehede of this body" (2685-2688). The images that Julian sees in this vision are no doubt an interpretation of the divine message shaped by her own experience as a child losing friends during the Black Death, or perhaps losing a child to the plague herself during one of the later outbreaks in her twenties. The experience of witnessing the deaths of children in her plague-ridden city would have been traumatizing memories, especially to a woman who seems to have such a gift for recalling visual memories in vivid detail when recounting her visions from decades prior in her book.

The first of two primary connections between the Passion and the plague is this idea of "foule" or "dede" flesh willingly taken on by Jesus in the hours leading up to his death. Some modern translations, such as the widely read version by Edmund Colledge and James Walsh, even use the phrase "black death" in some of these instances, such as in Chapter X of the Long Text: "It symbolized and resembled our foul black death, which our fair, bright, blessed Lord bore for our sins" (1978, p. 194). The original text does not include the word "black" in line 374, instead using the Middle English word "hame"2: "our foule dede hame." Presumably, Colledge and Walsh sought to sharpen the contrast of dark and light with "black death" against the "fair, bright, blessed lord." Either way, the connection to the later parable of the child's soul exiting the foul, mangled body as clean and whole is obvious. Another instance of Jesus taking on this foul dead flesh is in the centerpiece of Julian's book, the parable of the lord and servant, linking the foul dying flesh to

\footnotetext{
${ }^{2}$ Line notes in the Crampton modernization define "hame" as "skin, slough, mortal covering (fig., flesh)." Cervone (2015) draws comparisons to other uses of the word in contemporary writing, where it refers to a membrane of an eye which causes blindness, an article of clothing used as a disguise, or the shed skin of a snake.
} 
both the role of the eagerly obedient servant and the biblical Fall, where she writes that "our Savior was made fair, now white and bryte, and of endless cleness..." after shedding "Adams old kirtle" (2052-2054).

The second connection between the Black Death and the Crucifixion is in how the death of Jesus appears to her visually. Julian often distinguishes between "bodely" and "gostly" sight. She makes clear during chapters XVI and XVII while describing the Crucifixion that this is the bodely sight when she says that the gostly sight "I shal speke of in the thirty-first chapter" (616-617). Her description of Jesus dying on the cross is notable for not only including the detail of how Jesus's skin changed color from "pale" to "blew" to "brown blew" to "brown and blak" (590-596). She also notes how it appeared that he was dying over a long period of time, writing: "it semyd to me as if He had bene seven night dede, it menyth that the swete body was so discoloryd, so drye, so clongen, so dedely, and so peteuous as $\mathrm{He}$ had be seven night dede, continuly deyand" (610-613). This vision of Jesus's suffering as a discoloration of skin taking place over seven painful days while continually dying does not resemble a crucifixion which took less than a day. It most closely resembles, not by coincidence, a death from bubonic plague. Julian interprets this divine vision of the Crucifixion based on her own worldly experience.

Julian's vision of the moment of Jesus's death is a departure from not only how the event is described in the Bible, but in the writings of Richard Rolle dating from just before the Black Death. Rolle was a widely read author at the time, and is believed to have died of the bubonic plague in September 1349 (Knowles, 1961, p. 51). His "Meditations on the Passion," also called "Meditation A" and "Meditation B," are full of similes which describe the tortured body of Jesus in practical or domestic terms. He describes how after Jesus was beaten, his head "was bolned as an ouene kake" (74a), that his "body is like to a dufhouse, for a dufhouse is ful of holys: so is py body ful of woundes" (221-222b) or "like a boke written al with rede ynke: so is by body al written with rede woundes" (236-237b). This generally positive portrayal of the suffering of a dying man's body is totally absent in Julian of Norwich, or other survivors of the plague in England such as the Monk of Farne mentioned above. Perhaps comparing the body of a dying man to everyday objects was less appealing when seeing the revolting bodies of the dead and the dying was itself an everyday occurrence.

The goal of Rolle's meditations is superficially similar to Julian's descriptions of the Passion: to bring Christians closer to God by thinking about the suffering Jesus chose to undergo to save humankind. His plea to his readers to renounce sin is almost absurd in the length of its list of creatures which will eat the various parts of the corpses of those "wreched kaytifs" who do not meditate on Christ's suffering: "pou shalt be cast in a pitte vnder the erthe, whan todis, wormys, snakys and other venymous bestes shal ete pi eighen, thy nose, pi mouth, thy lippes, thi tonge, thy hede, thy hondes, thy fete, and al pi body" (161-165a). The fire-and-brimstone approach is radically different from Julian of Norwich's writings, and Julian's larger socio-political project is diametrically opposed to Rolle's. Although, Rolle makes mention of earthly authorities and medical language when he says of Jesus: "in pe is al souereyne medicyne, and I, lord, am al sek in synnes; perefor, swet Ihesu, tak me to pe, and set me vnder py cure" (83-84b). Elsewhere, he locates this cure directly 
in Christ's wounds (203b). At first, this may seem to be compatible with Julian's desire to link the wound in Jesus's side to either a mother's breast or a womb, and thereby to both motherhood in general and Holy Mother Church. However, Rolle's Jesus is always apart from others; his humanity is always in isolation. Not only that, but Jesus's suffering is only shared with Mary and John when they witness his crucifixion. It is necessary for one to choose to share Jesus's suffering, driving Rolle to jealousy of Mary for experiencing that pain in person and claiming that sharing Christ's suffering "shold haue be myne, for I had deserued hitte and was cause pereof," referring to Mary being born without original sin and therefore not needing Christ to die for her redemption (352-353b). Rolle's Jesus suffers for us and apart from us; Julian's Jesus suffers with us and among us. Julian views Jesus's suffering as suffering alongside the human beings who also wear the husk of foul mortal flesh and know all the pain which comes with it. The choice for Julian is not whether you accept the "cure" from Jesus, but whether you choose to see in him a commiserator and source of comfort through unity with him, rather than choosing to seek him out as a dispenser of discrete mementos of his pain as cure-alls, like the "drope of his rede blode" that Rolle craves to cleanse his own soul (365b).

Julian also uses medical language to describe being healed of sin by God, saying: "For be these medycines behovyth that every soule be helyd. Thow he be helyd, his wounds arn seen aforn God, not as wounds, but as worships" (1332-1333). The difference is that after the Black Death, when God did not send any literal cures to heal his worshipers, the interpretation of what form this cure would take necessarily changed. For Rolle, individual portions of Christ's blood and sacrificed body were a cure for all diseases, a belief which the Church itself held about the Eucharist in the time of the Black Death. ${ }^{3}$ In Julian's teachings, however, the "bodely sekenes of Gods sendyng" (1320) is itself the medicine which "cures" the soul of its separation from God. Through recognizing the common suffering of one's own mortal flesh and the suffering of the mortal flesh willingly taken on and painfully sacrificed by Jesus, a unity can be forged between human beings and God.

Julian rarely quotes directly from scripture or from historical figures but she makes an exception for Saint Dennis, who was said to have witnessed the natural disasters which accompanied Jesus's death on the cross:

...For whan he saw wonderous and mervelous sorowes and dreds that befallen in that tyme, he seyd, "Either the world is now at an end or ell He that is maker of kynde suf-fryth." Wherfor he did write on an auter, "This is the auter of onknown God." God of His godenes that maketh the planets and the elements to werkyn of kind to the blissid man and the cursid, in that tyme it was withdrawen from bothe. Wherefore it was that thei that knew Him not were in sor-

\footnotetext{
3 In a mass titled Salus populi, performed in Canterbury in 1382, the communion host was blessed with the words: "May the receiving of your sacrament prevent the fury of cruel death from coming upon us" (Horrox, 1994, p. 122). Outside of official Church documents, another instance can be found in a book of Italian folk medicine from an unknown date, titled A Wholesome Medicine against the Plague, advocating "the most delightful and precious medicine: the body of our lord and savior Jesus Christ" (1994, p. 149).
} 
row at that tyme. Thus was our Lord Jesus nawted for us, and we stond al in this manner nowtid with Hym. (687-694)

By giving this specific quote and the attendant explanation, Julian links the Crucifixion to natural disasters and offers a reason for them-the disasters are a reflection of Jesus's suffering, and mortal humans suffer with him. She shows that there are two possible responses to the Black Death: believe that God has withdrawn from the world, or recognize Jesus's suffering reflected in the horrific events beyond one's control. In siding with the latter over the former and stressing the unity of being "nawted" with him, she reasserts the presence of God and establishes the Crucifixion as a site of unity between human beings and her re-envisioned Holy Trinity.

Chapters XXVII and XXVIII elaborate on the spiritual side of surviving a plague, how one can gain the humility which comes from knowledge of the limitation of mortal bodies. This humility is essential for joining with God. It is in these chapters that the famous phrase "All shall be well" appears, in response to the question of why sin is allowed by God. Without sin, Julian initially believes, humans would all be as "clene and like to our Lord as He made us" (932-933). As mentioned above, this idea of being clean and untouched by $\sin$ is visually represented by a clean soul of a child leaving the deformed body that represents foul mortal flesh. "All shall be well" is a reassurance that within each soul, there is the substance made in God's image, which is untouched by the sins of the world. Often left out of the prayer books and shrines where "All shall be well" is quoted is the lead-in: "Synne is behovabil," as in the Modern English verb "to behoove" (938). Sin is necessary or befitting. After one of the greatest calamities England had ever seen, the problem of evil would have weighed heavily on the minds of English Christians. With this answer, Julian turns the Black Death into a blessing in disguise.

According to Julian, sin does not truly exist, "for it hath no manner of substance ne no party of being" and can only be known by the pain it causes (949-950). But it is from this pain that the redemptive quality which unites the human soul to God emerges: "for it purgith and makyth us to 10 knowen our selfe and askyn mercy" (951-952). God simultaneously wishes to cleanse his worshippers of their earthly pride and vanity while not blaming them for having these impure thoughts to begin with. Sin is "behovabil," because it provides the opportunity for humility afterwards. In Julian's only instance of portraying a wrathful God, she quotes Him as saying: "I shall al tobreke you for your veyn affections and your vicious pryde, and after that I shal togeder gader you, and make you mylde and meke, clene and holy, by onyng to me" (976-978). Note how God's wrath is used only as a tool for motivating an eventual reunification, just as Julian envisions the Black Death, thought to be sent by God, as an opportunity to bring grieving Christians closer to the divine.

The absence of blame for the flaws that come from foul mortality is a recurring subject throughout these two chapters. This serves a dual purpose in correcting a pair of negative tendencies in post-plague England, the first being people turning away from faith in God because they blame Him for the existence of sin and suffering. In addition to her belief that sin does not truly exist outside of the suffering it causes, which is in turn an opportunity to humble oneself and unite with Jesus on the cross, she points out that if God does not blame us for sin, nor should 
we blame Him: "Than were it a gret unkindness to blame or wonder on God for my synne, sythen He blamyth not me for synne" (958-959). Furthermore, the figure of the outcast, blamed and shunned for their sin during their earthly life, is blameless in God's eyes. This philosophy of blamelessness could serve as a refutation of a contemporary form of antisemitism, where Jews were blamed for spreading or causing the plague. No one is to blame for sin, and therefore no human being is to blame for either the plague or its biblical analogue in Jesus's suffering during the Passion. This blamelessness of Jewish people for the suffering of Christians is elaborated on when Julian describes her vision of the Crucifixion as containing no Jewish tormentors, as her predecessor Richard Rolle does (60a, 76b). With this, she not only breaks with an unfortunate tendency in medieval English writers such as Rolle, she must carefully walk a tightrope in order to avoid contradicting Church doctrine.

When discussing sin and the visions she had of the Crucifixion in Chapter XXXIII, she makes special mention of the fact that "the Jewes that deden Hym to ded" were absent, although she carefully mentions that through her faith she knew they were "accursed and dampnyd without end, savyng those that converten be grace" (1132-1134). The following chapter is entirely dedicated to her reaffirming her visions as being in accordance "with al the prechyng and techyng of Holy Church" (1155). She seems to be torn between investigating this lack of Jews in her vision and the need to reaffirm her belief in the Church's doctrine. She finds a way through this by mentioning that, according to the Church, Jews are damned, but she avoids blaming them for killing Jesus (this was "not so propirly specyfyed" in line 1132). The narrow line she walks in this passage is not only to save herself from the consequences of contradicting official dogma while she is being cloistered within a church as an anchoress, but also to preserve her vision of humans as blameless for the sins which lead to suffering like the Passion or the plague. And at the time of the Black Death, blame towards Jews was rampant.

A popular conspiracy theory at that time involved the poisoning of wells by Jews as the cause of the plague. Others went as far as claiming Jews somehow poisoned rivers and the air itself (Horrox, 1994, p. 56). While some historians have pointed to the connection between these conspiracy theories and pogroms during outbreaks of the plague, some modern scholars are investigating whether the already existing antisemitic violence increased during the early years of the plague (Cohn, 2002, p. 704). Jean de Venette, the Carmelite friar who theorized in the "imagination" explanation of plague transmission mentioned above, was a skeptic of these antisemitic theories from the outset. He stated that "such poisonings, even if they really happened, could not have been solely responsible for so great a plague or killed so many people" (Horrox, 1994, p. 57). Julian avoids the antisemitic scenes of Jewish tormenters because she does not want her readers to blame Jesus's suffering, and by extension the suffering of the plague victims, on Jews or anyone else. Sin causes suffering, and sin is "behovabil." There simply is not room in Julian's understanding of the nature of suffering for assigning blame. Looking for scapegoats to blame for the actual cause of the plague is counterproductive if the goal is to unite human beings with God through an understanding of the metaphysical reasons for the existence of suffering itself. 


\section{Holy Mother Church}

Two figures became more popular in art following the Black Death: a vengeful Jesus and his protective mother, Mary, who shields humanity from the worst of his wrath. ${ }^{4}$ Andrea Essner observes how this trend in mystic texts actually begins over a century earlier with the Ancrene Wisse having a family dynamic within the Holy Trinity that depicts Jesus not as the son but as the mother, stepping in to protect her child from an angry father intent on beating him. Essner observes that, during the Black Death, by "viewing the plague as God's punishment on humanity, Christians could identify with the punished children whom Christ would protect" (2008, p. 58). Moreover, Essner believes that associating Jesus with family during a time when many people lost parents or children to the disease "was appropriate during a time when the family unit was devastated by the plague" (2008, p. 68). Restoring unity to English society through an interpretation of the Holy Trinity would of course include a surrogate family for those who lost loved ones, so Julian did include a version of this idea, but not exactly as the earlier Ancrene Wisse had done.

Although Julian identifies Christ as a maternal figure, she does not have him protecting humanity from the patriarchal God's wrath, but instead choosing to suffer alongside them. The maternal nature of Christ comes in part from this sacrificial nature. Caroline Bynum remarks that in the portrayal of Jesus as a mother, there is the simultaneous generative/sacrificial nature: "the female is generative (the foetus is made of her very matter) and sacrificial in her generation (birth pangs)" (1984, p. 131). While Christ may not have created humanity, the creation of Adam and the Fall are extensively discussed in the parable of the lord and servant in Chapter LI and mention is made throughout of the same foul mortal flesh which is shared by both Jesus and Adam. Human beings are made of the same matter as Jesus, even if he did not create us himself. However, the suffering he shares with mortals is for their sake, to make it possible for them to escape Hell and be reborn into eternal life.

According to Bynum, the metaphorical birth is essential for understanding Julian's theosophical project: "Although fourteenth-century male writers such as Richard Rolle and the monk of Farne also emphasized the Crucifixion as birthing... the fullest development of a theology of motherhood as creation and redemption is by... Julian of Norwich, in whose hands it became a solution to the problem of evil" (2012, p. 163). To elaborate, the Crucifixion allows Christians who are suffering not to suffer alone, but rather to unite with Christ in the humility that comes from pain. The sin which causes the pain must exist in order for this state of affairs to come about, and Jesus's sacrifice redeems the sins of humanity, making them ultimately blameless. Essentially, the Crucifixion neutralizes all the negative elements of sin,

\footnotetext{
4 "It was characteristic of the age that Christ should often be portrayed as an angry and minatory figure... In pictures of the Virgin dating from before the plague she is often seen protecting monks and nuns from the wrath of God; significantly, after the plague, her mantle is extended to cover all Christian beings as well. Mankind, it is clear, could use all the protection it could get" (Ziegler, 1969, p. 276). While Ziegler does an admirable job of tracking these two figures separately as a historian, it is the work of literature scholars such as Caroline Bynum which will feature prominently going forward, in which the figures of Christ and the protective mother are combined.
} 
so, as Julian says, sin does not truly exist and one can only see it by the pain it causes.

Christian mystic texts written before the Black Death had no need to forge a maternal link with such profound implications between the suffering of their readers' everyday lives and Jesus's suffering on the cross, although a precursor to Julian, Bridgette of Sweden, also connected motherhood to the Crucifixion via a focus on Mary's suffering as a witness (Temple, 2016). Rolle included a birth metaphor with the Crucifixion. When the wound in Jesus's side was created by the Roman spear, "blode and watyre ran out" (541b). This imagery, combined with the maternal connotations of the wound in Jesus's side as a breast or a womb, does lend itself to a reading as a metaphorical birth. The link forged here is that between the end of life and the beginning; the moment of Jesus's death is our birth. Bynum also mentions two other qualities of motherhood attributed to Jesus other than a sacrificial generation: "loving and tender (a mother cannot help loving her child)" and "nurturing (she feeds the child with her own body)" (1984, p. 131). The latter figures into Rolle's conception of Jesus-as-mother through the water-wine-blood cycle, i.e. Christ turned water into wine at the wedding at Cana, wine into blood at the Last Supper, then when his side was pierced by the spear, water was released along with the blood. These three substances are miraculously linked, with one transubstantiating into the next in an endless loop. But in medieval understanding of the human body, blood was also converted into milk by a nursing mother's body (1984, p. 132). Like Jesus at the Last Supper, a mother converts her blood into sustenance for her children. While these images existed in the writing of Christian mystics for centuries before the Black Death, "between the twelfth and fourteenth centuries, the use of these images became 'darker'; suffering was increasingly stressed" (Bynum, 2012, p. 158). So it is not that the experience of Black Death revolutionized the portrayal of the motherly qualities of Christ, but rather that Julian uses these preexisting tropes to not only provide a spiritual mother figure for those who lost family in the plague, but also re-establishes the legitimacy of Holy Mother Church after the plague dealt a serious blow to its image.

To give a brief overview of public perception of religious authority in the aftermath of the Black Death, the Church faced two problems: it had lost a lot of priests, and their hastily chosen replacements were often unqualified, undertrained, and poorly received by the parishioners. Moreover, their early strategy of blaming sinners for provoking God's wrath made people feel unwelcome in the church and resentful towards it as the death toll mounted. The first of these complaints was remarked on by contemporary writers of Julian's, as in the anonymous poem "On the Pestilence" which reads "Alas! rectors and vicars have changed their ways, they're hirelings now, not true shepherds, and their works are motivated by the desire for money" (Horrox, 1994, p. 127). In Julian's (presumed) hometown of Norwich, the Bishop hired sixty clerks of no more than twenty-one years of age to hold church services "on the grounds, more or less categorically stated, that they would be better than nothing" (Ziegler, 1969, p. 262). ${ }^{5}$ Worse yet, the mortality rate among priests

\footnotetext{
5 Some modern scholars have looked at the trend of women entering the workforce after the plague due to lack of male laborers and have drawn a parallel with Julian of Norwich's status as the first known female author in the English language, filling an intellectual and spiritual gap left by authors such as
} 
was highest for those so faithful that they continued performing last rites for the dying and inevitably caught the plague themselves, whereas the cowardly ones who shirked their duties lived (1969, p. 262).

The other problem was one that Julian has tried to address, the question of blame. Unfortunately for the Church, the strategy of blaming the sinful for bringing God's wrath was deeply unpopular. In 1348, the Bishop of Bath and Wells roared "Almighty God uses thunder, lightning and other blows which issue from his throne to scourge the sons whom he wishes to redeem," in reference to the approaching plague then ravaging the continent (Horrox, 1994, p. 112). Another church official speculated that God was allowing the plague to arrive in England "because of the growing pride and corruption of its subjects and their numberless sins" (p. 114). "Fairly or unfairly," Ziegler writes, "medieval man felt the church had let him down. The plague, it was taken for granted, was the work of God, and the church assured him, with uncomfortable regularity, that he had brought it on his own head" (1969, p. 260). This prevalent attitude within the church and the backlash from without are the environment in which Julian tries to promote a peaceful reunion between the Church and its wayward flock. If people are blameless for their sins in God's eyes and God is blameless for their sins as well, as quoted above from lines 958-959, then the plague was no one's fault. A few lines later, Julian specifies that the Church has also suffered during this plague: "Gods servants, Holy Church, shal be shakyn in sorows and anguis and tribulation in this world, as men shakyn a cloth in the wynde" (966-968). Julian argues that the Church suffered alongside the Christian laypeople, much like how Jesus suffered alongside them. In fact, Julian argues, it is exactly like how Jesus suffered alongside them.

The figure of Jesus, the Son of the Holy Trinity, is a complex one in Julian's Shewings. He is simultaneously an aspect of God, a son, a mother, an avatar of humanity's suffering, the Church, and, later, a servant to a lord. While attempting to re-establish the authority of the Church, she draws several explicit parallels between the motherhood of Christ and Holy Mother Church. In dispensing the sacrament of the Eucharist, the Church is the agent through which the motherhood of Christ feeds Christians:

The Moder may geven hir child soken her mylke, but our pretious Moder Jesus, He may fedyn us with Himselfe, and doith full curtesly and full tenderly with the blissid sacrament that is pretious fode of very lif. And with al the swete sacraments He susteynith us ful mercifully and graciously. And so ment He in this blissid word wher that He seid, I it am that Holy Church prechith the and techith the. That is to sey, all the helth and lif of sacraments, al the vertue and grace of my word, all that godness that is ordeynid in Holy Church for the, I it am. (2501-2506)

\section{Footnote 5 (continued)}

Richard Rolle dying in the plague. It is possible that, as Catherine Innes-Parker writes, Julian saw herself as "[taking] on the priestly role as a mediator between God and the unlearned lay believers... in a role usually reserved for the clergy, that of a conduit of God's teaching and revelation" (1997, p. 15). 
Notably, this passage shows how the Church is the maternal Jesus not just in feeding her children, but raising them as well, teaching them right from wrong. This nurturing aspect is elaborated on in the following chapter, where the oft-quoted lines about how one must be willing to see Jesus as a child sees their mother appears, where a child who has fallen down runs to their mother and says "My kind Moder, my gracious Moder, my dereworthy Moder, have mercy on me. I have made myself foul and onlike to the, and I ne may ne can amenden it but with prive helpe and grace" (2569-2572). This image can be seen in works of art for over a century after the plague swept through Europe, as in a version of Vierge de la Miséricorde which includes people covered in plague buboes being protected under her mantle (Horrox, 1994, p. 97). The plague has made humanity foul and unlike their mother, but she can clean and heal them. It must be remarked upon that this parable is situated between examples of the Church as a mother, implying heavily that Christians must run to the Church with this child-like faith in her ability to clean and heal them. It is clear that rather than using the darker imagery of suffering and the motherly qualities of Christ as simple expressions of religious faith at a time of crisis, these pre-existing tropes have been deployed for the purpose of re-establishing the Church as a force for good in society during a time when people had begun to doubt its legitimacy.

There is a temptation for modern readers to impose the idea of being a feminist onto Julian of Norwich, that her claims of the motherhood of Jesus are subversive and allow her to launder her own credibility as a woman through the feminine qualities of the ultimate patriarchal authority figure. In her article "Subversion and Conformity in Julian's Revelation," Catherine Innes-Parker makes this claim, although not unreservedly, and stresses that this subversion and laundering of female authority is a necessity for an anchoress who must not openly promote her own views above those of the Church. Julian's use of the pre-existing concept of the motherhood of God is, to Innes-Parker, "one way in which she revises the images used by male authors in order to promote her own potentially subversive views while at the same time conforming to the structures in which she was confined" (1997, p. 22). If Julian's relationship to the Church was confined to the single passage where she must qualify her exclusion of antisemitic tropes in contradiction of Church dogma, perhaps this could be true. However, her views are far from subversive: Julian only comes close to subverting Church authority with her views on the blamelessness of sin. And it is this same logic of blamelessness which she uses, in part, to redeem the Church's image after the Black Death. Likewise, her use of a maternal Christ is not a feminizing of authority for the sake of her own credibility, but rather making the unwelcoming image of the Church more familiar and comforting; it gives the Church a softer, more nurturing image. The re-establishment of the legitimacy of the Church allows for devastated communities and families to have a single organization to rely on for relief and a sense of meaning. "For on singler person may oftentymes be broken, as it semyth to selfe, but the hole body of Holy Church was never broken, ne never shall, withouten end" (2579-2581). Despite Julian's protests to the contrary, the Church was, in fact, nearly broken by the Black Death: "the abrupt disappearance of nearly half the clergy, including a disproportionate number of the brave and diligent, inevitably put heavy strain on the machinery of the Church and 
reduced its capacity to effectively deal with movements of protest or revolt" (Ziegler, 1969, p. 262). And while the greatly reduced labor force may have resulted in women pursuing work outside the home, this was not the only economic consequence. The decades-long lead-up to the Peasants' Revolt in 1381 may have inspired the most significant addition between the Short Text and the Long Text, the parable of the lord and servant in Chapter LI.

\section{The Holy Ghost and the Zeitgeist}

As was the case for Julian's depiction of the motherhood of Christ, the Peasants' Revolt was the culmination of a long pattern extending from before the Black Death itself. There was already an economic decline before 1348, and the movement from a barter economy to use of currency for wages and rent had already begun. Instead the "sudden disappearance of so high a proportion of the labour force meant those who already worked for wages were able to demand an increase... If a landlord refused, conditions were particularly propitious for the [laborer] to slip away and seek a more amenable position elsewhere" (1969, p. 233). This included women as well, who began to work in traditionally male jobs such as farming, albeit with fewer hours and for half the wages of men, although during the harvest, this pay gap would sometimes shrink (Poos, 1991, p. 217). The Revolt resulted from an attempt by the crown to roll back wages to a pre-plague pay level and restrict the ability of workers to leave their employers for higher pay elsewhere. While this certainly benefitted the class interests of the landed gentry, it also protected smaller lords from having all of their servants hired away by the few wealthiest lords, concentrating wealth and power in a smaller number of individuals (Ziegler, 1969, pp. 248-249). What ultimately gave rise to the Peasant's Revolt was these laws which removed an opportunity for higher pay, and thus, for social advancement.

One reading of Julian's parable of the lord and servant would separate it entirely from the context of the Peasant Revolt. Julian is after all speaking of servants, not wage laborers. Servants tended to be unmarried young men and women who cooked and cleaned-paid, in part, with room and board in their lord's manor. This is a separate group from laborers, who were married adults living in their own homes who worked for a wage. Historian Laurence Poos calls this "the most fundamental distinction" of England's economy at that time (1991, p. 183). However, as he writes, "Late-medieval England did not possess a completely unambiguous terminology to denote what historians understand by 'servant' and 'labourer'" (p. 184). Indeed, Poos later cites an instance of a 'servant' in a 1409 document being a man being hired to do the manual labor of "digging ditches" (p. 204). This ambiguity seems to match how Julian uses the term "servant" in lines 1953-1955: "I beheld, thynkyng what manner labour it myte ben that the servant shud don, and than I understode that he shuld don the gretest labor and herdest travel that is. He shuld ben a gardiner, delvyn and dykyn," these last two terms meaning digging and ditch-digging. The contemporary meaning of "servant" as in domestic servant is here as well, where the servant lives with the lord and knows him as intimately as a live-in domestic worker would. Rather than separating the servant from connotations of wage labor, 
she plays with the ambiguity of the word at that time. This quasi-familial intimacy between lord and servant may have been common before the Black Death, but in its aftermath it was an anachronism, writes Frederick Bauerschmidt. He highlights especially the "feudal presumption that there is some sort of unbreakable, personal bond between lord and servant. When the servant fails to return, the lord cannot simply go out and hire another. Rather, he is bound to the servant as much as the servant is bound to him" (1999, p. 176). This is crucial to the underlying compassionate and inclusive message beneath what is otherwise a reactionary desire to return to a world where the servants are truly servile. The interdependency of the feudal classes is like a family to Julian. They have an innate love for each other and the blood in their veins is the same.

It is not necessary to recap all of Chapter LI, which is by far the longest and most detailed vision in the book. The essential details for this reading of the text are the link between the suffering of the servant, who is simultaneously Adam and Jesus; the reward which will be given for this suffering by the lord; and the way that the lord and servant love each other and both see their relationship as eagerly giving each other tokens of their devotion or gratitude. The first is the most complicated on its own, but throughout this essay I have already made the connections between suffering, plague victims, Jesus, a mother, and the Church. They all share foul mortal flesh, and their suffering is at its apex in the Passion. The second detail is how the suffering that human beings experience, as God's servants, will be rewarded: "fallith it not to me to gevyn a geft that be better to hym and more worshipfull than his own hole shuld have ben? And ell me thynkyth I dede hym no grace" (1836-1838). Lastly, when Julian herself explains this she clarifies that the lord loves his servant just as the servant loves his lord:

And in this an inward gostly shewing of the lords menyng descendid into my soule, in which I saw that it behovith neds to ben, stondyng his grete and his own worship, that his dereworthy servant which he lovid so mech shuld ben verily and blisfully rewardid without end aboven that he shuld a ben if he had not fallen; ya, and so ferforth that his fallyng and his wo that he hath taken therby shall be turnyd into hey and overpassing worship and endles bliss. (1838-1843)

In this idealized version of feudalism, the lord knows and loves his servants/ laborers, and will reward them for the suffering they endure as a result of their eagerness to serve him. This belief in the mutual generosity of feudal class relations not only explains why the plague was actually beneficial in the long-term for some great reward, but also calls for a return to this intrinsic bond between lord and servant as a prerequisite for receiving this reward, seemingly condemning the practice of workers leaving their masters to find better pay elsewhere. In Julian's vision, the only reason for a servant to not return is because he loves his lord so much that his love becomes distracting, resulting in injury. The greatest reward one can find is not from being hired by another lord who can pay better, but from serving your own lord to the point of suffering for it.

Once the idea that one could leave their lord to find better wages elsewhere began to spread, there was a feeling of betrayal from some of the less wealthy lords since 
some of these wage laborers only fled as far as the neighboring manor. This seemed unnatural, fracturing a link that was once commonly believed to exist between the worker, the lord, and the land. Workers became fungible and mobile, and therefore the "pattern of several centuries was breaking up; not only the pattern of society but the set of men's minds as well" (Zeigler, 1969, p. 239). Part of Julian's political project is to re-familiarize people with feudalistic class relations as a loving relationship, in the same way that she re-familiarized people with thinking of the Church as a motherly relationship.

Not only does Julian connect the Holy Trinity to the earthly institutions of the Church and static feudal class-relationships, in which people had had their faith shaken by the Black Death and its aftermath, but connects these to each other using the same vocabulary of love. Love is made up of two components, the mercy of the mother and the grace of the feudal lord (1697-1700). The mother was of course linked to the Church; the lord is alternately compared to the Father of the Holy Trinity (the God of the Old Testament, as the lord-and-servant parable is in part a retelling of the Fall from the book of Genesis) and elsewhere to the Holy Ghost: "our good Lord the Holy Gost" (1677). She later explains that, like a feudal lord, the Holy Ghost compensates people for their work: "And in our good Lord the Holy Gost we have our rewarding and our yeldyng for our lifyng and our travel" (2403-2405). Most significantly, she attaches lordship to fatherhood and motherhood when outlining how she saw the Holy Trinity in her vision: "I beheld the werking of all the blissid Trinite, in which beholdyng I saw and understode these three properties: the properte of the faderhede, the properte of the moderhede, and the properte of the lordhede in one God" (2397-2399). Julian makes use of the ambiguity of the word servant to mean either a live-in domestic worker or a manual laborer to make the lord-servant relationship part of a household, another authority in one's home other than one's parents.

Having tied the three aspects of the trinity metaphorically to the lives of English Christians via the institutions of medieval England and the home, Julian now must link their lives to the Holy Trinity more literally. While the Son and the Holy Ghost are mercy and grace, respectively, the Father is "kinde," as in "alike in kind" (2408). The "substance" of the human soul is made not only by God, it is made of God: "But to the makyng of manys soule, He wold take ryte nought, but made it. And thus is the kynd made rytefully onyd to the maker, which is substantial kynd onmade, that is God" (2192-2194). It is through this that human beings truly enter into the Trinity, not as the children of mother Jesus or the servants of the lord Holy Ghost, but as consubstantial with God. With a subtle knot resulting from the manner of their creation, all human souls are "onyd" to God (2205).

It is this final element which redeems this political reading of Julian of Norwich's Shewings. A reductive version of this, seeing only the attempt to re-legitimize the authority of the Church and the endorsement of restricting the free movement of workers, would seem reactionary. Finding the positive side of suffering only in how it makes one humble and servile seems to justify cruelty and subjugation. However, the Catholic theological concept of consubstantiality shows that earthly authorities are not to be meekly obeyed, but are reflections of a heavenly interconnectedness of human souls and God. "Consubstantiality" usually refers to the idea that all three 
parts of the Holy Trinity are made of the same substance, but Julian of Norwich adds the human soul into this concept, saying that it, too, is consubstantial with God, and by extension must also be consubstantial with Jesus and the Holy Ghost. In this way, the earthly institutions that Julian links to the Holy Trinity are consubstantial with humanity: earthly institutions such as the Church or the economic system of feudalism are made of people who suffer in foul mortality alongside each other. Julian points out that the Church is made up of "Gods servants, Holy Church, [who] shal be shakyn in sorows and anguis and tribulation in this world, as men shakyn a cloth in the wynde" (968-969). The Church's officials, the feudal lords, and the public at large are all bodies of foul mortal flesh, made of the same earthly substance, the "slype of erth" that God made all bodies from (2191). Furthermore, it is not a linear hierarchy from human to more powerful human to God. Rather, it is an infinitely nesting loop, like a Russian doll without an end or a beginning. Humans are within the Trinity, both making up and being subject to these institutions which represent them on Earth, but the Trinity is within each human as well:

The hey goodnes of the Trinite

is our lord, and in Him we arn beclosid, and He in us. We arn beclosid in the Fadir, and we arn beclosid in the Son, and we arn beclosid in the Holy Gost; and the Fader is beclosid in us, and the Son is beclosid in us, and the Holy Gost is beclosid in us...

...For it is not ell but a rythe understondyng with trew

beleve and sekir troste of our beyng that we arn in God, and God in us, which we se not. (2225-2234)

\section{Conclusion}

After the Black Death, the English needed to renew their belief in the institutions which shaped their lives. By recognizing their shared experience of suffering through the plague, Julian of Norwich uses this common suffering as a foundation for her effort to reunite people with the institutions of the Church and feudal classrelations, comparing them not just to the Holy Trinity, but to a wealthy and loving household. Some scholars have pointed to the use of familial terms describing the Holy Trinity in this era as the creation of surrogate families for those who lost loved ones to the plague, but Julian was far more ambitious. In her visions of suffering and the nature of the Trinity, she sought to create in the Trinity a surrogate society.

\section{Funding None.}

Availability of data and material Not Applicable.

Code availability Not Applicable. 


\section{Declarations}

\section{Conflicts of interest None.}

\section{References}

Bauerschmidt, F. (1999). Julian of Norwich and the mystical body politic of Christ. University of Notre Dame Press.

Bynum, C. W. (1984). Jesus as mother: Studies in the spirituality of the High Middle Ages. University of California Press.

Bynum, C. W. (2012). Fragmentation and redemption: Essays on gender and the human body in medieval religion. Zone Books.

Cervone, C. M. (2015). Julian of Norwich and John Capgrave: Foule black dede hame / Hame of blyndnes. The Journal of English and Germanic Philology, 114(1), 88-96.

Cohn, S. K. (2002). The Black Death: End of a paradigm. The American Historical Review, 107(3), $703-738$.

Colledge, E., \& Walsh, J. (1978). Julian of Norwich: Showings. Paulist Press.

Crampton, G. R. (1994). The Shewings of Julian of Norwich. Medieval Institute Publications.

Essner, A. (2008). God as mother in post-Black Death English mystical texts. Magistra, 14(2), 56-74.

Horrox, R. (1994). The Black Death. St. Martin's Press.

Innes-Parker, C. (1997). Subversion and conformity in Julian's revelation: Authority, vision and the motherhood of God. Mystics Quarterly, 23(2), 7-35.

Knowles, D. (1961). The English mystical tradition. Harper \& Brothers.

Lawes, R. (2000). Psychological disorder and the autobiographical impulse in Julian of Norwich, Margery Kempe and Thomas Hoccleve. In D. Renevey \& C. Whitehead (Eds.), Writing religious women: Female spiritual and textual practices in late medieval England (pp. 217-244). University of Toronto Press.

Poos, L. R. (1991). A rural society after the Black Death: Essex 1350-1525. Cambridge University Press.

Temple, L. P. (2016). Returning the English "mystics" to their medieval milieu: Julian of Norwich, Margery Kempe and Bridget of Sweden. Women's Writing, 23(2), 141-158.

Ziegler, P. (1969). The Black Death. The John Day Company.

Publisher's Note Springer Nature remains neutral with regard to jurisdictional claims in published maps and institutional affiliations. 